\title{
Aesthetic and functional rehabilitation of anterior teeth after trauma: a case report
}

\begin{abstract}
- Kelly Guedes de Oliveira Scudine Department of Pediatric Dentistry, Piracicaba Dental School, University of Campinas, Campinas, SP, Brazil - Kelly Maria Silva Moreira Department of Pediatric Dentistry, Piracicaba Dental School, University of Campinas, Campinas, SP, Brazil - Micaela Cardoso Department of Pediatric Dentistry, Piracicaba Dental School, University of Campinas, Campinas, SP, Brazil • Stéphanie Marani Martins Araújo Piracicaba Dental School, University of Campinas, Campinas, SP, Brazil • Regina Maria Puppin-Rontani Department of Pediatric Dentistry, Piracicaba Dental School, University of Campinas, Campinas, SP, Brazil • Eduardo César Almada Santos Department of Pediatric Dentistry, Piracicaba Dental School, University of Campinas, Campinas, SP, Brazil
\end{abstract}

ABSTRACT | Traumatic dental injuries are common clinical problems during childhood, and may have complex etiologies causing physical and physiological impairment. The aim of this study was to report the management of a severe traumatic dental injury in an 8-year-old female patient, victim of a motorcycle accident, who was taken to a pediatric dentistry clinic three months after the accident. After clinical and radiografic examination, we observed the avulsion of the permanent maxillary central incisors and of the permanent left lateral incisor, with considerable lingual interposition, interfering in speech and swallowing. The patient showed low risk of caries and good behavior during the appointments. However, she demonstrated to be embarrassed to smile. Besides the preventive treatment concerning caries, the treatment plan included immediate care and subsequent monitoring of the psychosocial reestablishment. For this purpose, an acrylic partial denture was made in order to replace the missing anterior teeth, maintaining the characteristics of the mixed dentition and preserving the aesthetics and the function. Follow-up appointments were performed one, three and six months after the first visit, aiming to monitor the adaptation of the prosthesis, as well as the growth and development of the child's dentition. Thus, the aesthetic and functional rehabilitation was achieved regarding the patient's satisfaction, enabling immediate social reinsertion.

DESCRIPTORS | Tooth Avulsion; Pediatric Dentistry; Mixed Dentition.

RESUMO | Reabilitação estética e funcional dos dentes anteriores após trauma: um relato de caso • Lesões dentárias traumáticas são problemas clínicos comuns durante a infância e podem ter etiologias complexas, causando deficiências físicas e fisiológicas. O objetivo deste estudo foi relatar um caso de lesão dentária traumática grave em uma paciente de 8 anos de idade, vítima de um acidente de moto, que foi levada para uma clínica de odontopediatria três meses depois do acidente. Exames clínicos e radiológicos diagnosticaram a avulsão dos incisivos centrais superiores permanentes, do incisivo lateral esquerdo permanente e do canino esquerdo decíduo, com considerável interposição da língua, interferindo na fala e deglutição. A paciente apresentou baixo risco de cárie e bom comportamento durante as consultas. No entanto, ela demonstrou estar envergonhada para sorrir. Além do tratamento preventivo para a cárie, o plano de tratamento incluiu atendimento imediato e acompanhamento posterior do restabelecimento psicossocial da paciente. Para este efeito, uma prótese parcial acrílica foi feita para substituir os dentes anteriores que faltavam, mantendo as características da dentição mista e preservando sua estética e função. Consultas de acompanhamento foram realizadas em um, três e seis meses após a primeira visita, com o objetivo de monitorar a adaptação da prótese, bem como o crescimento e desenvolvimento da dentição da criança. Assim, a reabilitação estética e funcional foi alcançada considerando a satisfação da paciente, permitindo sua reinserção social imediata.

DESCRITORES | Avulsão Dentária; Odontopediatria; Dentição Mista.

CORRESPONDING AUTHOR | • Eduardo César Almada Santos Department of Pediatric Dentistry, Piracicaba Dental School, University of Campinas • Avenida Limeira, 901, Areião Piracicaba, SP, Brazil •13414-018 E-mail: almada@unicamp.br

- Received May 5, 2017 • Accepted Nov. 16, 2017

- Dol http://dx.doi.org/10.11606/issn.2357-8041.clrd.2017.132567 


\section{INTRODUCTION}

Dental trauma is an important public health problem due to frequency, costs, and occurrence at a young age, therefore, it requires monitoring of the treatment for the rest of the patient's life. ${ }^{1}$ Traumatic dental injuries are very common problems in children, and several studies reported that the prevalence of these injuries has increased in the past few decades, particularly due to parents' need to leave their children with caregivers. ${ }^{2,3}$

Dental trauma is commonly caused by damages such as falls, fights, vehicle accidents, domestic violence, and sports. ${ }^{2,} 4$ Moreover, oral factors, such as increased overjet with protrusion, human behavior and environmental determinants are also risk factors for dental trauma. ${ }^{5}$

Permanent tooth traumas usually include the maxillary anterior teeth ${ }^{6}$ and are very frequent in children and adolescents due to their active lifestyles. Regarding the type of trauma in this dentition, avulsion is the most serious one and accounts for $7.6 \%$ of all permanent tooth traumas. 7 Traumatic injuries to the anterior teeth result in functional, aesthetic and phonetic problems. $^{8}$

These traumatic injuries are painful and distressing events that affect not only the children, but also their guardians. Psychological and social impacts have become an important sequel of dental trauma that can impair the child's social functioning, emotional balance, and well-being. ${ }^{9,10}$ When anterior teeth are fractured or lost, children are often self-conscious and hesitant to return to school without an aesthetic tooth replacement. ${ }^{11}$

Since aesthetic considerations should not be neglected and rehabilitation treatment always request priority, both on a functional and physiologic level, ${ }^{11,12}$ the aim of this study was to report the management of a traumatic injury in a child victim of a motorcycle accident that caused the avulsion of three maxillary incisors.

\section{CASE}

This case report describes the management of a severe dentoalveolar trauma involving the avulsion of the maxillary central incisors and the left lateral incisor teeth in an 8-year-old female patient. The guardian reported that the child was victim of a motorcycle accident. The patient consulted the pediatric dentistry clinic of the Piracicaba Dental School complaining about aesthetic problems due to the missing maxillary anterior teeth. Her mother reported that the child was in excellent health with no remarkable past medical history.

During the first examination, three months after the trauma, we observed that the injuries were limiting the child's oral cavity, and a notable lingual interposition was interfering in speech and swallowing. We observed that the patient presented Angle Class I malocclusion and that some permanent teeth were missing (right and left central and left lateral maxillary incisors) and a left maxillary primary canine. In addition, it was observed a gingivites evolving the first left maxillary premolar and a residual root possibly from the first maxillary primary molar (Figure 1A D), which was searched by the radiographic exam. Even though the child was a low caries risk patient with no previous caries history on primary dentition, she showed an arrested caries lesion on the distal fissure of the first maxillary molar (Figure 1E). Accuracy of periapical and panoramic radiographs were performed to verify root fracture or any other dental injuries. Therefore, radiographic exams confirmed the avulsion of the permanent maxillary central incisors (right and left) and the left lateral incisor (Figure 2). 


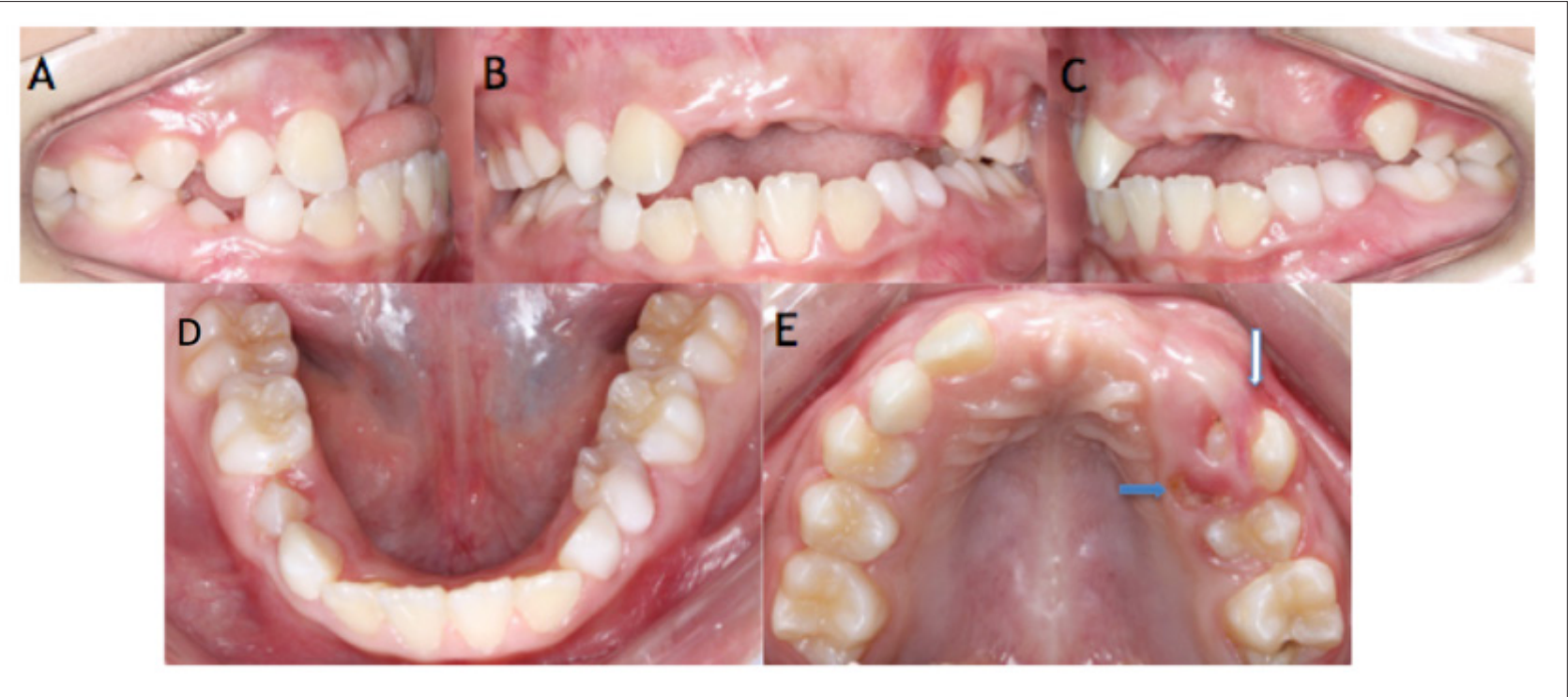

Figure 1 || Oral conditions at the first appointment, three months after the accident. A. Right lateral occlusal view; B. Frontal occlusal view right and left central incisors and the left lateral incisor are missing; C. Left lateral occlusal view; D. Inferior occlusal view; E. Superior occlusal view. Note that the patient has low caries risk, with the four first molars free from caries; at the superior arch, only the right primary canine is shown (D) and at the inferior arch, both canines, both second primary molars and the left first primary molar are shown (D). Blue arrow shows a residual canine root; white arrow shows gingivitis surrounding a first premolar starting to erupt; black arrow shows a caries lesion paralyzed on the distal fissure of the left first molar.

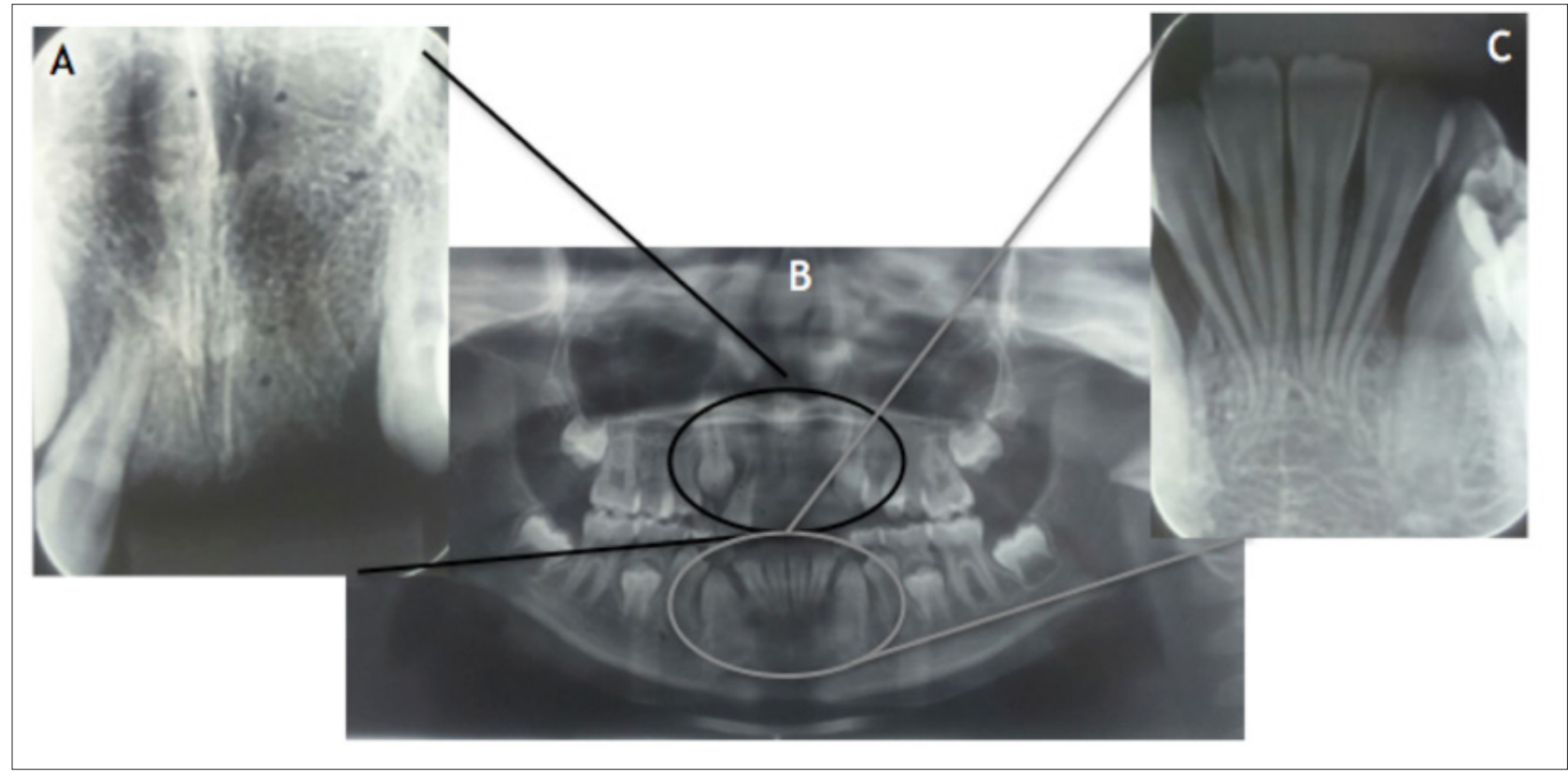

Figure 2 | Panoramic and bitewing radiographic exams. A. Panoramic radiography showing a panoramic view. Only the maxillary arch was affected by the trauma; B. Bitewing radiography from maxillary central region. Right and left central and left lateral incisors are missing; C. All mandibular incisors are healthy. 
The treatment plan included the replacement of the missing anterior teeth with an acrylic denture (Clássico, São Paulo, SP) and stock teeth (Dentsply, Rio de Janeiro, Brazil) to reach the aesthetic and functional rehabilitation, focused on the child's emotional and physical reestablishment. An expander screw was added to the partial denture to release and monitor the development of the maxilla, since the growth of the arch width was not complete. 13 In addition, a midline diastema was performed because this is a common part of the dental development in the period of mixed dentition (Figure 3).

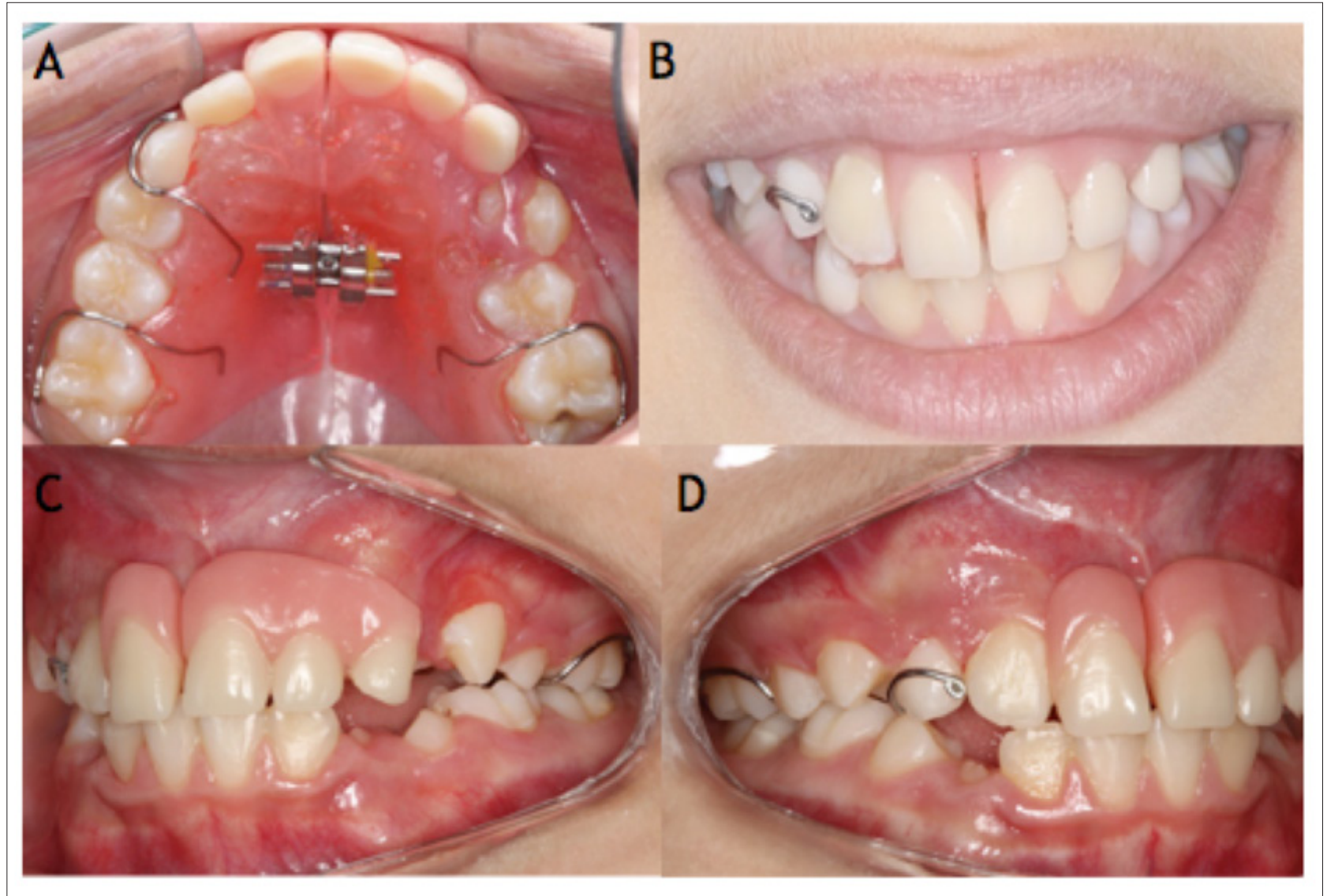

Figure 3 | Aesthetic and functional rehabilitation after trauma. A. Superior occlusal view; B. Frontal occlusal view; C. Left lateral occlusal view; D. Right lateral occlusal view. Note that the residual canine root was extracted.

Furthermore, more appointments were performed to treat other dental issues, such as pit and fissure sealant, oral hygiene education and tooth brushing skills. Follow-up examinations were done one, three and six months after the first visit. The clinical success was evaluated according to the patient's satisfaction regarding the tooth size, morphology and color, improvement on phonetics, swallowing and chewing ability. The patient engaged on the proposed treatment and kept using the partial denture.

In addition, wear was carried out inside the acrylic on the left side so the canine could erupt. Activations were made on the dental screw, opening a diastema between the central incisors, which would be acceptable at this age. The patient will be monitored until the establishment of the permanent dentition, when new evaluation should be conducted to verify the need for full appliance. 


\section{DISCUSSION}

Treatment of dental trauma in primary and permanent dentition is sometimes neglected, indicating a low level of knowledge regarding emergency management of dental trauma by professional caregivers and lay people. ${ }^{14,15,16}$ Another reason could be the economic and social status of the patients. ${ }^{17}$ According to Osuji (1996), only $11 \%$ of patients sought treatment on the same day of trauma, while $10 \%$ searched it over one year later. In agreement with the results found, in our case, there was a delay of three months in the search for dental treatment after the accident, which could have serious consequences on the occlusal development. Regarding the cases involving avulsion, we can mention the inclination of the adjacent teeth and extrusion of the antagonist teeth due to lack of occlusal contact. In addition, anterior teeth have the important function to protect the posterior teeth during excursive mandibular movement, and consequently, their loss induces posterior interference with extended disocclusion time. Posterior disocclusion is important to avoid the harmful force on the temporomandibular joint and to reduce muscle hypertonicity. ${ }^{18}$ It emphasizes the need to improve oral health awareness, so parents can seek for their children's treatment as soon as any episode of dental trauma occurs.

An association was identified between the history of anterior teeth avulsion and the occurrence of lingual interposition during swallowing, as well as with speech disorders. In addition, the loss of the anterior teeth compromises the balance of the orofacial muscles, resulting in loss of lip and muscle tonus. ${ }^{19}$ These findings increase the need of early treatment before these disorders appear. The authors reported that the loss of anterior teeth might reduce social acceptance, induce low self-esteem and poor quality of life, 9, 10 as we observed in this case. After placing the partial denture, we observed that the patient was more communicative and friendly, indicating the success of the treatment.

The approach chosen in this case was a partial denture because it is practical and simple to make and modify, if necessary. Furthermore, it is considered an alternative treatment until anterior alveolar bone growth has been completed and implants can be applied. ${ }^{20}$ Therefore, long-term follow up is essential, especially for children in developing dentition.

\section{CONCLUSIONS}

Dental rehabilitation with an acrylic partial denture was a satisfactory treatment option and is indicated for similar cases of anterior tooth avulsion in mixed dentition, reestablishing the child's aesthetic, functional and psychological needs.

\section{ACKNOWLEDGMENTS}

The authors thank Espaço da Escrita, General Coordination Office of University of Campinas, for the language services provided, and declare no conflict of interests.

\section{REFERENCES}

1. Glendor U. Epidemiology of traumatic dental injuries: a 12 year review of the literature. Dent Traumatol. 2008 Dec;24(6):603-11. doi:10.1111/j.16oo-9657.2008.00696.x.

2. Bastone EB, Freer TJ, McNamara Jr. Epidemiology of dental trauma: a review of the literature. Aust Dent J. 2000 Mar;45(1):2-9. doi: 10.1111/j.1834-7819.200o.tboo234.x.

3. Andreasen JO. Etiology and pathogenesis of traumatic dental injuries: a clinical study of 1,298 cases. Scand J Dent Res. 1970;78(4):329-42.

4. Kumamoto DP, Maeda Y. A literature review of sports-related orofacial trauma. Gen Dent. 2004 May-Jun;52(3):270-80.

5. Glendor U. Aetiology and risk factors related to traumatic dental injuries: a review of the literature. Dent Traumatol. 2009;25(1):19-31. doi:10.1111/j.1600-9657.2008.00694.x.

6. Delattre JP, Resmond-Richard F, Allanche C, Perrin M, Michel JF, Le Berre A. Dental injuries among schoolchildren aged 
from 6 to 15, in Rennes (France). Endod Dent Traumatol. 1995 Aug;11(4):186-8. doi: 10.1111/j.1600-9657.1995.tboo485.x.

7. Zerman N, Cavalleri G. Traumatic injuries to permanent incisors. Endod Dent Traumatol. 1993 Apr;9(2):61-4. doi: 10.1111/j.1600-9657.1993.tboo661.x.

8. Oz IA, Haytaç MC, Toroglu MS. Multidisciplinary approach to the rehabilitation of a crown-root fracture with original fragment for immediate esthetics: a case report with 4-year follow-up. Dent Traumatol. 2006 Feb;22(1):48-52. doi: 10.1111/j.1600-9657.2006.00335.x.

9. Lee JY, Divaris K. Hidden consequences of dental trauma: the social and psychological effects. Pediatr Dent. 2009 Mar-Apr;31(2):96-101.

10. Holan G, Needleman HL. Premature loss of primary anterior teeth due to trauma: potential short, and longterm sequelae. Dent Traumatol. 2014 Apr;30(2):10o-6. doi: 10.1111/edt.12081.

11. Robertson A, Norén JG. Subjective aspects of patients with traumatized teeth. A 15-year followup study. Acta Odontol Scand. 1997 Jun;55(3):142-7. doi: 10.3109/00016359709115407.

12. Saha R, Malik P. Paediatric aesthetic dentistry: a review. Eur J Paediatr Dent. 2012 Mar;13(1):6-12.

13. Proffit WR. Contemporary Orthodontics. 2nd ed. Saint Louis, MO: Mosby-Year Book; 1993.

14. Namdev, R.; Jindal, A.; Bhargava, S.; Bakshi, L.; Verma, R.; Beniwal, D. Awareness of emergency management of dental trauma, Contemp Clin Dent. 2014 Oct-Dec;5(4):507-513. doi: 10.4103/0976-237X.142820.

15. Glendor U. Has the education of professional caregivers and lay people in dental trauma care failed? Dent Traumatol. 2009 Feb;25(1):12-8. doi: 10.1111/j.1600-9657.2008.00707.x.

16. Osuji OO. Traumatised primary teeth in Nigerian children attending University Hospital: the consequences of delays in seeking treatment. Int Dent J. 1996 Jun;46(3):165-70.

17. Govindarajan M, Reddy VN, Ramalingam K, Durai KS, Rao PA, Prabhu A. Prevalence of traumatic dental injuries to the anterior teeth among three to thirteen-year-old school children of Tamilnadu. Contemp Clin Dent. 2012 AprJun;3(2):164-7. doi: 10.4103/0976-237X.96819.

18. Haralur SB, Al-Shahrani OS. Replacement of missing anterior teeth in a patient with temporomandibular disorder. Case Rep Dent. 2014;2014. doi:10.1155/2014/393627.

19. Haralur SB, Al-Qahtani AS. Replacement of missing anterior teeth in a patient with chronic mouth breathing and tongue thrusting. Case Rep Dent. 2013;2013. doi: 10.1155/2013/759162.

20. Day PF, Kindelan SA, Spencer JR, Kindelan JD, Duggal MS. Dental trauma: part 2. Managing poor prognosis anterior teeth: treatment options for the subsequent space in a growing patient. J Orthod. 2008 Sep;35(3):143-55. doi: 10.1179/146531207225022590. 